\title{
Recycled metaigneous crustal sources for S- and I-type Variscan granitoids from the Spanish Central System batholith: Constraints from Hf isotope zircon composition
}

\author{
Carlos Villaseca ${ }^{a, *}$, David Orejana ${ }^{a}$, Elena A. Belousova ${ }^{\text {b }}$ \\ a Departamento de Petrología y Geoquímica (UCM), Instituto de Geociencias (UCM-CSIC), Madrid, Spain \\ ${ }^{b}$ GEM C, Department of Earth and Pianetaly Sciences, Macquarie University, NSW 2109, Australia
}

Keywords:

$\mathrm{U}-\mathrm{Pb}$ dating

Zircon Hf-isotope composition

Peraluminous granites

Spanish Central System

Variscan Iberian Belt

\begin{abstract}
A B S T R A C T
The Spanish Central System (SCS) is one of the largest granite batholiths in the European Variscan Belt Zircons from five granitic intrusions from the eastern SCS have been separated and analysed for Hf isotopes by laser ablation MC-ICPMS, in order to evaluate the nature of granitic magma source. Two samples are cordierite-bearing S-type granites, the rest are amphibole-bearing I-type monzogranites. Hf-isotope composition of zircons from these granites defines a narrow range of negative $\varepsilon \mathrm{Hf}$ values $(-1.1$ to -5.8$)$, typical of crustal protoliths. The within-sample variation of zircon Hf isotope composition is slightly above the analytical uncertainty ( $\pm 1.5 \varepsilon$ units), suggesting the mixing of different magma batches during pluton assembly. The S- and I-type granites display the same range of initial $\varepsilon \mathrm{Hf}$ values, that is in agreement with previous data showing that both SCS granite types have similar ( $\mathrm{Sr}, \mathrm{Nd}, \mathrm{O}, \mathrm{Pb}$ ) isotope signatures. These isotopic data suggest that they derived from similar sources, while the variation in peraluminosity could be related to different partial melting conditions.

The presence of a Lower Ordovician inherited zircon population (478-462 Ma), at least in I-type granites, suggests the involvement of Cambro-Ordovician orthogneisses as components in the source of some SCS granites. Inherited zircon population of similar age has also been identified in the SCS lower crustal granulites. The Hf-isotope composition of the analysed granite zircons is within that of zircons from the above granulites. Moreover, some evidence of a juvenile input at 560-595 Ma is recorded by Hf-isotope data in zircons from both the SCS granites and granulite xenoliths. Hf-isotope signature, in conjunction with other chemical, isotopic ( $\mathrm{Sr}, \mathrm{Nd}, \mathrm{O}, \mathrm{Pb}$ ) and geochronological evidences, suggests that SCS granites were probably derived from metaigneous lower crustal sources. The Variscan magmatism in central Spain is dominantly a crustal reworking event.
\end{abstract}

\section{Introduction}

Widespread granite magmatism is a common phenomenon in continental collision zones. It usually occurs during late-orogenic crustal thinning overprinting the previous metamorphic history. The Iberian Massif forms part of the European Variscan Belt which resulted primarily from the oblique collision of two continents: Gondwana and BalticaIaurentia, from Early Devonian to Mid Carboniferous (e.g. Matte, 2001). The Central Iberian Zone (CZ) represents the innermost region of this collisional belt and is characterised by large volume of granitic intrusions outcropping from central Spain to NW Iberian Peninsula (Fig. 1). The understanding of the age, composition and petrogenesis of granitic intrusions is important for the understanding of the evolution of the continental crust as a whole.

\footnotetext{
* Corresponding author at: Department of Petrology and Geochemistry (UCM), Institute of Geosciences (UCM-CSIC), Complutense University of Madrid, C/José Antonio Novais 2, 28040, Madrid, Spain. Tel.: + 3491394 4910; fax: + 34915442535

E-mail address: granito@geo.ucm.es (C. Villaseca).
}

The Spanish Central System (SCS) is one of the largest granite batholiths in the European Variscan Belt. It is composed mainly of post-kinematic S- and I-type granitoids, and mafic rocks are very rare. However, conspicuous mafic microgranular enclaves appear within monzogranite of both S- and I-type granitoids. The nature of the protoliths involved during crustal melting has been thoroughly discussed: some authors favour crustal recycling of different protoliths: i) metaigneous lower crustal sources (Villaseca et al., 1999) or metasedimentary mid-crustal sources (Bea et al., 1999, 2003). The lack of crustal sources at outcropping levels with isotopic signatures similar to those of granites led other authors to suggest an important role of mantle-derived additions to the crustal melting (e.g. Castro et al., 1999; Pinarelli and Rottura, 1995). Therefore, more data are needed to further constrain the chemical evolution of this magmatism and precisely define the composition of the sources involved.

The record of magmatic evolution from bulk granite composition is sometimes difficult because it delivers averaged information (e.g. Appleby et al., 2010; Kemp et al., 2007). This record is, however, preserved within the chemical and isotope stratigraphy 


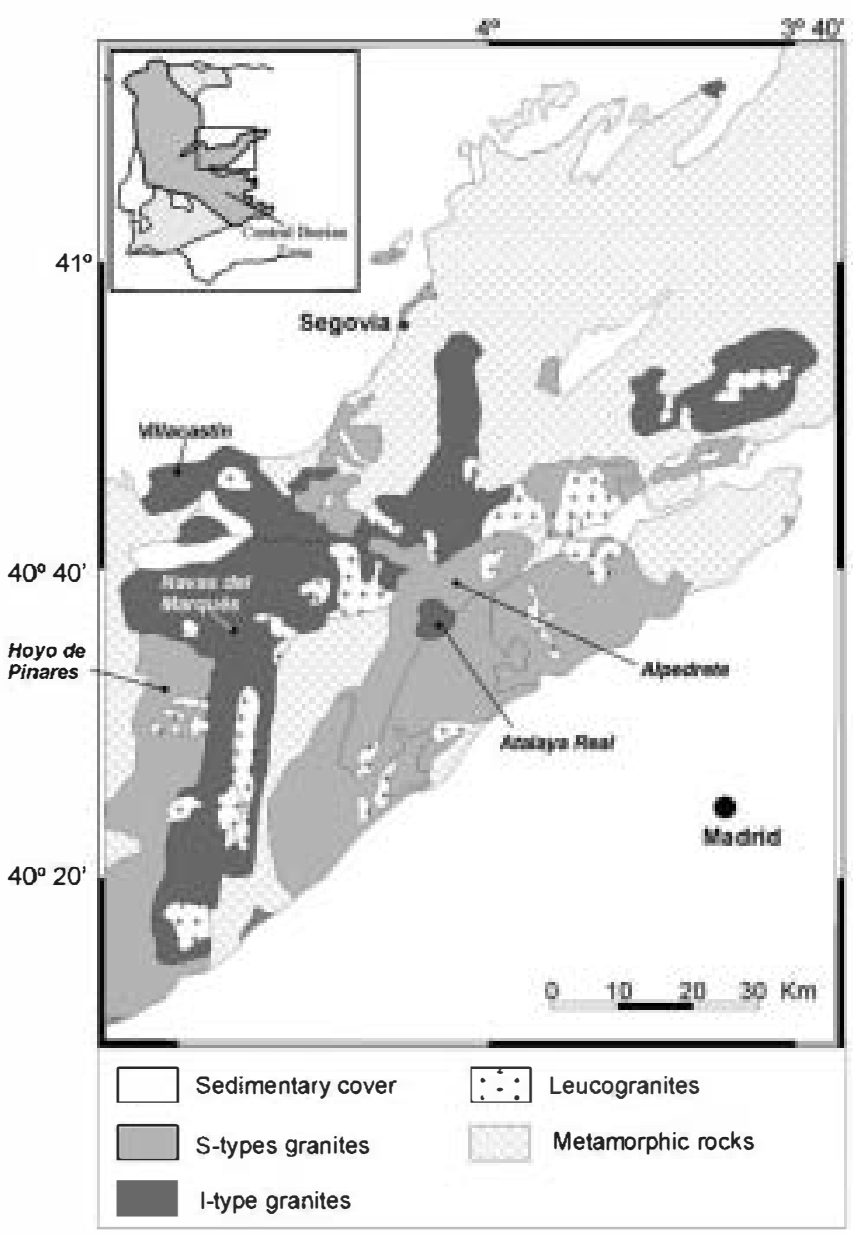

Fig. 1. location of the Spanish Central System within the Iberian Massif and geological map of the SCS eastern sector, showing the sampling location of the five plutons considered in the present study.

of certain minerals. Zircon has the advantage that its intricate zoning can be dated by $\mathrm{U}-\mathrm{Pb}$ isotopes, and it retains chemical information about the evolution of its host melt in its Hf-isotope composition (e.g. Griffin et al., 2002). For the present study we have analysed Lu-Hf isotopes in zircons previously dated by ion microprobe $\mathrm{U}-\mathrm{Pb}$ methods using the SHRIMP instrument. The sampling consists of five representative granites from the easternmost part of the Spanish Central System (SCS): the Sierra de Guadarrama (Fig. 1). Zircon separates from these samples have been analysed by laser ablation ICP-MS to determine their Hf isotopic composition. An approach based on combined $\mathrm{U}-\mathrm{Pb}$ and Lu-Hf isotope systematics on zircon grains is ideally suited to identify possible heterogeneous source components in the granites (e.g. Kurhila et al., 2010). An accurate Hf-isotope geochemistry of this felsic magmatism in the Spanish Central System is still lacking, and the data presented in this study add to this objective. To date, only one study on integrated $\mathrm{U}-\mathrm{Pb}$ and $\mathrm{Hf}$ isotope studies of zircon from Variscan Central Iberian granites has been undertaken (in northern Portugal: Teixeira et al., 2011).

The coincidence in $\mathrm{Sr}, \mathrm{Nd}, \mathrm{Pb}, \mathrm{O}$ isotopic signatures between $\mathrm{S}$ - and I-type granites of the SCS has been previously described in works suggesting similar granite sources (e.g. Villaseca and Herreros, 2000; Villaseca et al., 2009). It is important to realise that recent granite studies based on zircon micro-analytical works in S-type granites have shown that infracrustal sources, similar to those involved in Itype granites, participate in their genesis. Thus, the original model of Chappell and White (1974) of contrasted granite sources would be questionable (e.g. Appleby et al., 2010; Solá et al., 2009). This work adds to the discussion on the nature of crustal sources involved in Sand I-type granite genesis, and also on the suggestion that parental melts for both magma types could be similar in composition (e.g. Clemens et al., 2011).

\section{Geological and geochronological background}

The Spanish Central System batholith is composed of more than 100 intrusive units which configure one of the largest exposures of granitic intrusions in the European Variscan Belt (Bea et al., 1999; Villaseca and Herreros, 2000). Most granitoids can be classified as monzogranite, with minor proportions of leucogranites and granodiorites (e.g. Villaseca et al., 1998). Almost all of them are peraluminous and display silica contents chiefly from 67 to $76 \mathrm{wt} \%$ (Villaseca and Herreros, 2000). Variations in their mineralogy and degree of Al saturation have led to subdivision in several series: 1) S-type peraluminous cordierite-bearing granitoids, 2) I-type weakly peraluminous to metaluminous amphibole-bearing granitoids and 3) transitional biotite granitoids of intermediate peraluminous affinity (Villaseca and Herreros, 2000). The geochemical data do not display strong differences between types, but S-type granites have a slightly higher $\mathrm{Al}$ saturation index due to their slightly lower $\mathrm{CaO}$ and $\mathrm{Na}_{2} \mathrm{O}$ contents compared to I-type granites (Villaseca et al., 1998), that explains the presence of local accessory hornblende in the latter. The relatively similar composition between SCS S- and I-type granites, both in trace elements and isotopic ratios (Villaseca et al., 1998), likely reflects the participation of similar source components (Villaseca and Herreros, 2000). A remarkable coincidence and major overlap in chemical plots have also been found in other I- and S-type granite suites (e.g. Clemens et al., 2011). Nevertheless, some SCS I-type granites show a strong enrichment in $\mathrm{Th}, \mathrm{Y}, \mathrm{Nb}$, and HREE for samples with silica in the range $74-76 \mathrm{wt} \%$ suggesting that different accessory phases are involved in S- and I-type granites during fractional crystallisation processes (Orejana et al., 2012; Villaseca et al., 1998).

The twofold division of granites in S- (supracrustal, sedimentary precursors) and I-types (infracrustal and igneous precursors) developed in the Iachlan Fold Belt of southeastern Australia (Chappell and White, 1974), failed to explain the complex petrogenetic histories of granites that are mixtures of several source types (e.g. Appleby et al., 2010; Shaw et al., 2011). In the SCS batholith, I-type granites overlap in many chemical plots with S-type granites, including ( $\mathrm{Sr}, \mathrm{Nd}, \mathrm{Pb}, \mathrm{O}$ ) isotopic ratios, suggesting the involvement of similar sources for both granite magma types (e.g. Villaseca and Herreros, 2000; Villaseca et al., 2009). Nevertheless, various hypothesis regarding the origin of the SCS granitic batholith have been suggested: a) hybridisation of crustal melts and mantle-derived magmas (Moreno-Ventas et al., 1995; Pinarelli and Rottura, 1995); b) crustal assimilation by mantlederived magmas (Castro et al., 1999; Ugidos and Recio, 1993); and c) partial melting of essentially crustal sources, either from lower crustal derivation (Villaseca et al., 1998, 1999) or from mid-crustal levels (Bea et al., 1999, 2003).

These granitic bodies intrude into Neoproterozoic to Lower Palaeozoic sequences of metasedimentary and metaigneous rocks of variable metamorphic degree, inducing thermal aureole metamorphism Most of the SCS granitoids intrude after the main phases of ductile deformation (D2-D3 of Macaya et al., 1991), which are coeval with migmatisation and low-pressure/high temperature M2 metamorphism $\left(\sim 725^{\circ} \mathrm{C}\right.$ and 4.5 kbar), after an initial M1 Barrovian metamorphic event $\left(\sim 750^{\circ} \mathrm{C}\right.$ and $14 \mathrm{kbar}$ ) (Barbero and Villaseca, 2000; Escuder-Viruete et al., 1998). Peak low $\mathrm{P} /$ high temperature metamorphism is constrained at about $330 \mathrm{Ma}$ (Castiñeiras et al., 2008; Escuder-Viruete et al., 1998; Montero et al., 2004). The high-grade gneisses have provided Ar-Ar muscovite and $\mathrm{K}-\mathrm{Ar}$ biotite ages of 314-310 Ma (ValverdeVaquero et al., 2007), which reflect cooling below $350^{\circ} \mathrm{C}$. The fact that granite units have intruded in shallow level, epizonal conditions (less than 2 kbar; e.g. Villaseca and Herreros, 2000), and produced 
contact metamorphism in the high-grade gneisses, indicate that the country rock in the eastern sector of the SCS batholith, was already cold at the time of intrusion. The granite magmatism is late- to postkinematic with respect to the local D4 phase of deformation, which is equivalent to the regional D3 phase of upright folding in the Central Iberian Zone of Díez Balda et al. (1990).

Initial attempts to determine the age of the SCS felsic magmas suggested an extensive time period of granite intrusion from 323 to 284 Ma (Bea et al., 1999; Ibarrola et al., 1987; Moreno-Ventas et al., 1995; Pinarelli and Rottura, 1995; Villaseca et al., 1995). These geochronological data were mainly based on whole-rock $\mathrm{Rb}-\mathrm{Sr}$ isochron method, resulting in poorly reliable data spreading in a wide age range. Recent U-Pb SHRIMP analyses on zircons from granites of western SCS yield ages concentrated in the range 314-303 Ma (Bea, 2010; Bea et al, 2009; Díaz-Alvarado et al., 2011; Montero et al., 2004; Zeck et al., 2007b). In the eastern end of the SCS batholith, a recent work establishes a granite timing of intrusion of 305 to $298 \mathrm{Ma}$ (Orejana et al. 2012).

The scarce coeval basic to intermediate magmas which accompany the granite intrusions are represented by small gabbroic to quartzdioritic plutons (Orejana et al., 2009; Scarrow et al., 2009). Recent U-Pb zircon studies constrain the age range of this basic input to 307-300 Ma (Bea et al., 2006; Zeck et al., 2007b; Villaseca et al., 2011a).

\section{Field relations and petrography}

\subsection{S-type intrus ions (Alpedrete and Hoyo de Pinares)}

These intrusions outcrop over areas near $350 \mathrm{~km}^{2}$ (Alpedrete) and $130 \mathrm{~km}^{2}$ (Hoyo de Pinares) (Fig. 1). They are mainly peraluminous coarse-grained cordierite-bearing biotite monzogranites and granodiorites. Leucogranites, which are also present in lower proportions, are generally interpreted as highly fractionated magmas derived from the monzogranitic parental melt (Villaseca et al., 1998 and references therein). Porphyritic textures with K-feldspar phenocrysts up to $4 \mathrm{~cm}$ long can be found locally. Rounded or elongated mafic microgranular enclaves (biotite-rich quartz-diorites to tonalites) are abundant and may be dispersed or concentrated in bands, showing fine-grained texture and size up to $50 \mathrm{~cm}$. It is also possible to find schlieren structures, micaceous enclaves and metamorphic xenoliths. Plagioclase is usually idiomorphic and display normal zoning. K-feldspar is also idiomorphic. Biotite is an early crystallising mineral, being sometimes altered to chlorite, whereas muscovite is secondary and substitutes cordierite and feldspar. Cordierite appears as interstitial crystals variably transformed to pinite. Its texture and composition suggest a magmatic origin (Villaseca and Barbero, 1994). Typical accessory phases are apatite, zircon, monazite, xenotime, ilmenite, and rare andalusite in aplo-pegmatitic veins.

\subsection{I-type intrusions (Villacas tín, Navas del Marqués and Atalaya Real)}

The Villacastin and Navas del Marqués plutons are large, relatively irregular intrusions outcropping over 150 and $300 \mathrm{~km}^{2}$, respectively (Fig. 1). They intruded into low-to-high grade metamorphic rocks, inducing contact aureoles in the wall-rocks. The Atalaya Real pluton is a small rounded body within the Alpedrete granite (Fig. 1). These I-type intrusions are mainly metaluminous to weakly peraluminous amphibolebearing biotite monzogranites and granodiorites, with minor leucogranitic facies. Similarly to the S-type intrusions, mafic microgranular enclaves can be found in these I-type granitoids, although in the Atalaya Real granites they are very scarce. Plagioclase shows oscillatory zoning and, together with biotite, is the main major early crystallising mineral. $\mathrm{K}$ feldspar is normally interstitial and may poikilitically include plagioclase, quartz and biotite. Amphibole is a green Mg-hornblende. Biotite is a good discriminant for SCS I-type granites as it plots in subaluminous fields below more Al-rich S-type biotites (Fig. 2 of Villaseca et al., 2009).
Localised banding has been observed in Villacastín, whereas biotitic schlieren and metamorphic xenoliths near the contact are common in the three plutons. Flow textures appear in the most porphyritic facies. Occasionally, clinopyroxene (augite/diopside) is present as a residual mineral included in plagioclase. Apart from apatite, zircon, monazite, xenotime and ilmenite, other important accessory phases in these rocks are allanite and tanite.

\section{Analytical procedures}

Zircons were separated from whole rock using standard crushing and mineral separation techniques, and handpicked before mounting
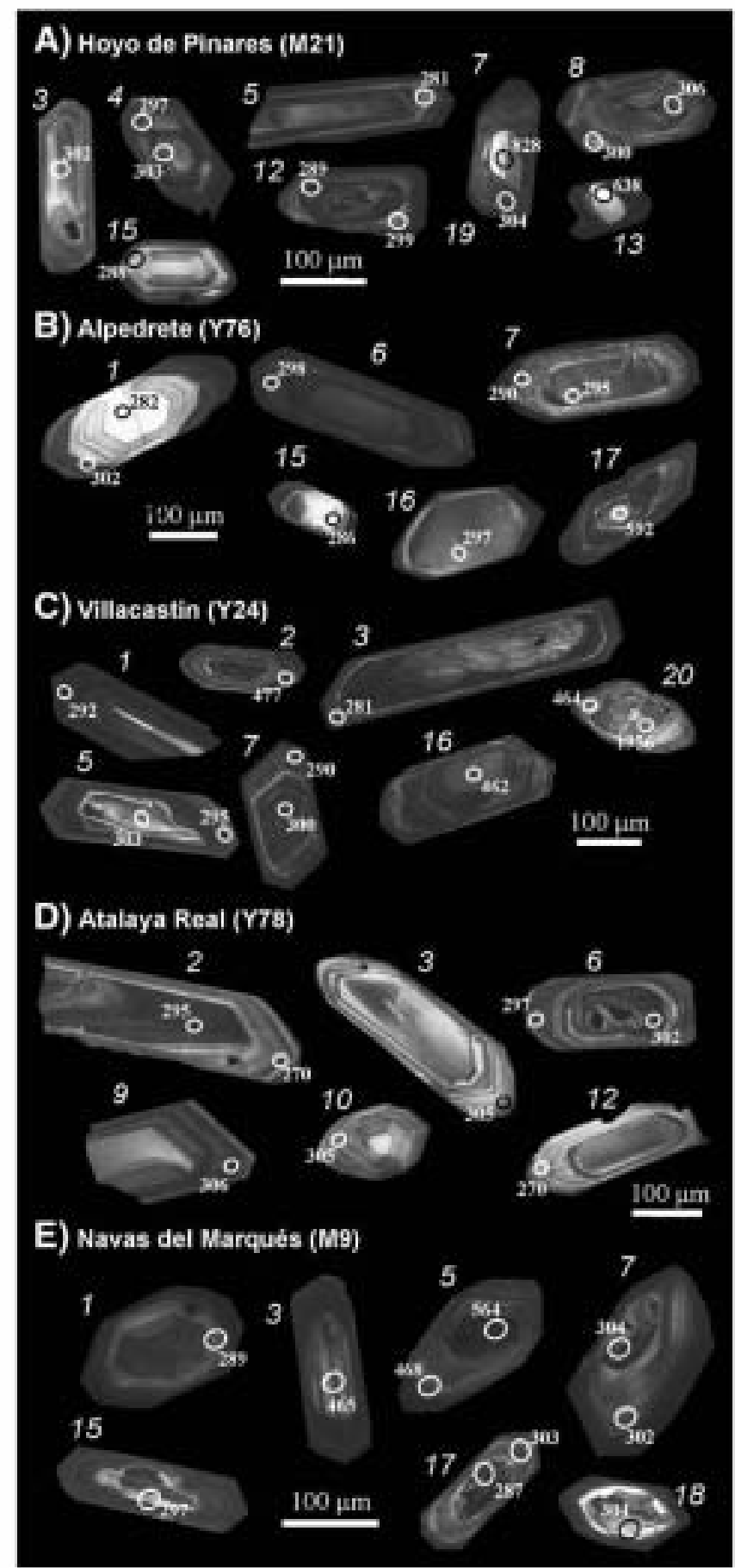

Fig. 2. CL images of representative zircon grains from the SCS granite intrusions with the analysed spots and concordia ages. 
on double-sided tape on glass slides in $1 \times 6 \mathrm{~mm}$ parallel rows together with some chips of zircon standard. After setting in epoxy resin, zircons were polished to expose their central portions and imaged with transmitted and reflected light on a petrographic microscope, and with cathodoluminescence to identify internal structures, inclusions, fractures and other crystal defects. Zircon U-Pb analyses were previously performed using SHRIMP-RG at the Research School of Earth Sciences, of The Australian National University (Orejana et al., 2012). U-Pb data and their uncertainties have been published and thoroughly discussed in that work. Because inaccurate $\mathrm{U}-\mathrm{Pb}$ ages would result in artificial trends of the Hf isotopic compositions, we have not used the data obtained with over $27 \%$ discordance for the following discussions, in a similar manner as it was done in recent publications (e.g. lizuka et al., 2010).

Lu-Hf isotopes were analysed on the same SHRIMP spots. Hf-isotope analyses were performed using a New Wave Research LUV213 laserablation microprobe, attached to a Nu Plasma multi-collector ICPMS at the GEMOC Key Centre, Macquarie University, Sydney. The laser system delivers a beam of $213 \mathrm{~nm}$ UV light from a frequency-quintupled $\mathrm{Nd}$ : YAG laser. Analyses were carried out with a beam diameter of $40-$ $55 \mu \mathrm{m}$, a $5 \mathrm{~Hz}$ repetition rate, and energies of $5-7 \mathrm{~mJ} / \mathrm{cm}^{2}$. This results in total $\mathrm{Hf}$ signals of $1-6 \times 10^{-11} \mathrm{~A}$, depending on conditions and $\mathrm{Hf}$ contents. Typical ablation times were $100-120 \mathrm{~s}$, resulting in pits $30-$ $40 \mu \mathrm{m}$ deep. Ar carrier gas transported the ablated sample from the laser-ablation cell via a mixing chamber to the ICPMS torch. The Nu Plasma MC-ICPMS features and other analytical procedures are those described by Griffin et al. $(2002,2004)$.

To evaluate the accuracy and precision of the laser-ablation results, and to test the reliability of the correction protocols, we have repeatedly analysed two zircon standards: 91500 and Mud Tank (MT). These reference zircons gave ${ }^{176} \mathrm{Hf} /{ }^{177} \mathrm{Hf}=0.282310 \pm 0.000049(2 \sigma)$ and $0.282502 \pm 0.000044(2 \sigma)$, respectively, which are identical to average published values on solutions of $0.282306 \pm 0.000008$ for 91500 and $0.282507 \pm 0.000006$ for MT (Woodhead and Hergt, 2005). The $2 \sigma$ uncertainty on a single analysis of ${ }^{176} \mathrm{Lu} /{ }^{177} \mathrm{Hf}$ is $\pm 0.001-0.002 \%$ (about 1 epsilon unit), reflecting both analytical uncertainties and the spatial variation of $\mathrm{Lu} / \mathrm{Hf}$ across many zircons. The ${ }^{176} \mathrm{Lu}$ decay constant value of $1.865 \times 10^{-11} \mathrm{a}^{-1}$ was used in all calculations (Scherer et al., 2001). Chondritic ${ }^{176} \mathrm{Hf} /{ }^{177} \mathrm{Hf}=0.282772$ and ${ }^{176} \mathrm{Lu} /{ }^{177} \mathrm{Hf}=0.0332$ (Bouvier et al., 2008) and the depleted mantle ${ }^{176} \mathrm{Hf} /{ }^{177} \mathrm{Hf}=0.28325$ $(\varepsilon \mathrm{Hf}=+16.4)$ and ${ }^{176} \mathrm{Lu} /{ }^{177} \mathrm{Hf}=0.0384$ were applied to calculate $\varepsilon \mathrm{Hf}$ values and model ages used in this work.

\section{Zircon description and $\mathrm{U}-\mathrm{Pb}$ data}

Zircon aspect ratios range from stubby (1:1 aspect ratio) to elongated (5:1), and are dominantly between 2:1 (e.g. Fig. $2 A \# 4,12$ ) and 3:1 (e.g. Fig. 2B \#1, 7). They show variable size, normally ranging from $80-100 \mu \mathrm{m}$ to $450-500 \mu \mathrm{m}$, though in samples M9 and M21 they do not exceed 250 and $300 \mu \mathrm{m}$, respectively. A common feature of zircons from all samples is the presence of irregular cores separated from rims by resorption surfaces (e.g. Fig. 2B \#17; Fig. 2C \#7). This texture appears associated with pre-Variscan and Variscan cores. No textural differences have been found between zircons grains from S- and I-type granites. More detailed information on size, external morphology and inner texture of zircons from granite samples have been provided by Orejana et al. (2012).

Zircons from sample M21 (Hoyo de Pinares) yielded a concordia age of $299 \pm 1.8 \mathrm{Ma}$ (Orejana et al., 2012). Nearly $40 \%$ of the mounted grains contain some kind of inner core truncated by the zircon rim, although only a third of them yielded pre-Variscan ages of 619 to $828 \mathrm{Ma}$ (Orejana et al., 2012). The remainders are Variscan zircons displaying variable zoning patterns (oscillatory, convoluted, sector zoning) (Fig. 2A).

Most zircon grains of sample Y76 (Alpedrete) have inner cores. Most of them are euhedral cores followed rimwards by oscillatory zoning (e.g. Fig. 2B \#1). Others are truncated, indicating resorption
(Fig. 2B \#6, 7). A third type is homogeneous cores with euhedral to subhedral shapes (Fig. 2B \#16). All of them are Variscan in age (288 to $308 \mathrm{Ma}$, Orejana et al., 2012), giving values similar to the $302 \pm$ 3.4 Ma estimated age of emplacement for the Alpedrete granite (Orejana et al., 2012). Only two resorbed anhedral zircon cores yielded pre-Variscan ages: 581-592 Ma (Orejana et al., 2012).

Sample Y24 from Villacastín granite shows elongated zircon grains characterised by rimwards oscillatory zoning. An age of $301 \pm$ $0.55 \mathrm{Ma}$ was obtained (Orejana et al., 2012). Independent of their habits, zircon grains present truncated cores with variable internal structures: oscillatory zoning and convoluted zoning (Fig. 2C). Two subhedral and poorly elongated (2:1 aspect ratios) inherited grains and one inherited core followed by oscillatory rims gave Ordovician ages (462 to $474 \mathrm{Ma}$ ). The oldest inheritance (1959 Ma) in SCS granites was found as a corroded core within an Ordovician zircon grain in this sample (Fig. 2C \#20).

Zircons from sample Y78 (Atalaya Real granite) yielded a concordia age of $306 \pm 0.4 \mathrm{Ma}$ (Orejana et al., 2012). This is the only SCS granite sample that does not show inherited zircons. Similarly to the S-type Alpedrete granite, it is characterised by the presence of homogeneous zircon cores concordant with the outer oscillatory zoning (Fig. 2D \#12). Discordant or truncated corroded cores are rare and display convoluted zoning.

Zircons from sample M9 (Navas del Marqués granite) yielded a concordia age of $300 \pm 2.6 \mathrm{Ma}$ (Orejana et al, 2012). Fine oscillatory zoning is the dominant internal structure. The most elongated prisms rarely show inherited cores, but these are common in the stubby or poorly elongated zircons. Cores might be divided between 1) texturally concordant inner areas of Variscan age, and 2) variably truncated or corroded irregular cores (Fig. 2E; \#3, 15). Inherited zircon domains appear as irregular cores though some stubby pre-Variscan grains (xenocrysts) may lack a significant magmatic rim (Fig. 2E \#5). The inheritances are Ordovician, in a restricted range of ages from 465 to $478 \mathrm{Ma}$, similar to that observed in the Villacastin sample (Orejana et al., 2012). Furthermore, an Ordovician zircon xenocryst shows an older core of Neoproterozoic age ( $564 \pm 6 \mathrm{Ma}$, Fig. 2E \#5).

\section{Lu-Hf isotopic data}

The Lu-Hf isotopic data obtained for the dated zircons are summarised in Table 1 and plotted as a function of their crystallisation ages in Figs. 3 and 4.

The depleted mantle model age ( $T_{D M}$ ) of a rock in the continental crust reflects the time elapsed from the last isotopic equilibrium of the system with a depleted mantle reservoir, and is therefore an estimate of the crustal residence age for the protolith (e.g. Andersen et al., 2002). However, because of the low Lu/Hf ratio of zircon, a model age calculated from the measured ${ }^{176} \mathrm{Lu} /{ }^{177} \mathrm{Hf}$ ratio of a zircon gives only a minimum limit for the crustal residence age. A more realistic model age for crustal rocks is calculated using a growth curve for a system with a Lu/Hfratio corresponding to the average continental crust $(0.015)$, through the zircon initial ${ }^{176} \mathrm{Hf} /{ }^{177} \mathrm{Hf}$ ratio (e.g. Griffin et al., 2002). This two-stage model age $\left(\mathrm{T}_{\mathrm{DM} 2}\right)$ would provide a better estimate for model ages of the source of granitic rocks presented in this study (Table 1). Nevertheless, it should be noted that model ages represent the accurate timing of the crust generation only if the parental magma lacked a mixed component (Andt and Goldstein, 1987), otherwise it provides the hybrid age of a multi-component system, and consequently a minimum age for the reworked crust (e.g. lizuka et al., 2010).

\subsection{Hoyo de Pinares granite, M21}

Variscan zircons yield initial ${ }^{176} \mathrm{Hf} /{ }^{177} \mathrm{Hf}$ ratios of $0.282513-$ 0.282429 which corresponds to $\varepsilon \mathrm{Hf}_{(\mathrm{t})}$ of -2.6 to -5.6 (Fig. 3). Inherited Neoproterozoic cores (in the age range of $619-828 \mathrm{Ma}$ ) 
show a higher ${ }^{176} \mathrm{Hf} /{ }^{177} \mathrm{Hf}_{(\mathrm{t})}$ range, and consequently higher $\varepsilon \mathrm{Hf}_{(\mathrm{t})}$. from -0.1 to -3.6 (Fig. 4). The $\varepsilon \mathrm{Hf}$ values for inherited cores calculated at $299 \mathrm{Ma}$ ranges from -7.4 to -14.6 which are lower than those obtained for their respective rims suggesting that relict isotopic heterogeneities are preserved in the granite (c.f., Flowerdew et al., 2006). The $T_{D M 2}$ range obtained for Variscan zircons is relatively small from 1.48 to $1.67 \mathrm{Ga}$ (Table 1), and slightly older than the value calculated with the whole-rock Nd depleted model age $(1.26 \mathrm{Ga})$ (Villaseca et al., 1998). Hf model ages for inherited Neoproterozoic cores give older values from 1.59 to $1.94 \mathrm{Ga}$.

\subsection{Alpedrete granite, $Y-76$}

Variscan zircons of this S-type granite yield a similar range of initial ${ }^{176} \mathrm{Hf} /{ }^{177} \mathrm{Hf}$ values $(0.282533-0.282422)$ when compared with data from sample $\mathrm{M} 2$, which corresponds to $\varepsilon \mathrm{Hf}_{(\mathrm{t})}$ of -1.8 to -5.8 (Table 1, Fig. 3). Inherited Neoproterozoic cores give positive $\varepsilon \mathrm{Hf}_{(\mathrm{t})}$ values of +2.3 to +3.2 (Fig. 4). $\varepsilon \mathrm{Hf}$ values of these cores calculated at 302 Ma overlap those of Variscan rims suggesting zircon dissolution in a closed system melting scenario (Flowerdew et al., 2006). The $T_{D M 2}$ range obtained for Variscan zircons is $1.44-1.69$ Ga (Table 1), which agrees well with the whole-rock Nd depleted model age $(1.58 \mathrm{Ga})$. In contrast, Hf model ages for inherited Neoproterozoic cores give younger values from 1.33 to $1.40 \mathrm{Ga}$ (Table 1 ).

\subsection{Villacas tín granite, $Y-24$}

Variscan zircons yield initial ${ }^{176} \mathrm{Hf} /{ }^{177} \mathrm{Hf}$ ratios of 0.282514 0.282405 which corresponds to $\mathrm{EHf}_{(\mathrm{t})}$ of -2.5 to -4.3 . This represents a smaller range of isotopic variation than in S-type granites, but slightly higher than the precision of the laser ablation method (Table 1). The $T_{D M 2}$ range for Variscan zircons is $1.48-1.59 \mathrm{Ga}$ (Table 1), which includes the value obtained for the whole-rock Nd depleted model age $(1.50 \mathrm{Ga})$. Ordovician zircons yield low initial ${ }^{176} \mathrm{Hf} /{ }^{177} \mathrm{Hf}$ ratios $(0.282100-0.282405)$, giving high negative $\mathrm{EHf}_{(\mathrm{t})}$ of -2.5 to -13.6 (Table 1), and a corresponding Paleoproterozoic $T_{D M 2}$ range (1.62 to $2.30 \mathrm{Ga}$ ) (Table 1). The $\varepsilon \mathrm{Hf}$ values for Ordovician cores at $306 \mathrm{Ma}$ ranges from -6.1 to -17.1 which are lower than those obtained for their rims suggesting again that relict isotopic heterogeneities are preserved in this granite. The inherited Paleoproterozoic core gives a slightly negative $\varepsilon \mathrm{Hf}_{(\mathrm{t})}$ value of -1.0 , and a correlative late-Archean $T_{D M 2}$ value of $2.67 \mathrm{Ga}$ (Table 1 ).

\subsection{Atalaya Real granite, $Y-78$}

This sample only presents Variscan zircons which yield initial ${ }^{176} \mathrm{Hf} /{ }^{177} \mathrm{Hf}$ ratios of $0.282519-0.282436$ which corresponds to $\varepsilon \mathrm{Hf}_{(\mathrm{t})}$ of -2.2 to -5.2 (Table 1 ). Their $T_{D M 2}$ range is $1.47-1.65 \mathrm{Ga}$ (Table 1 ), slightly higher than the value calculated with the whole-rock $\mathrm{Nd}$ depleted model age $(1.34 \mathrm{Ga})$.

\subsection{Navas del Marqués granite, M9}

Variscan zircons of this sample yield the larger range of initial ${ }^{176} \mathrm{Hf} /{ }^{177} \mathrm{Hf}$ ratios of the studied SCS granites $(0.282551-0.282420)$ which correspond to $\varepsilon \mathrm{Hf}_{(\mathrm{t})}$ of -1.2 to -5.9 (Table 1), a range larger than the analytical uncertainties. The $T_{D M 2}$ range for Variscan zircons is $1.40-1.69 \mathrm{Ga}$ (Table 1 ), which encompasses the value calculated with the whole-rock $\mathrm{Nd}$ depleted model age $(1.61 \mathrm{Ga})$. Inherited Ordovician zircons give a wider range of $\varepsilon \mathrm{Hf}_{(\mathrm{t})}$ values of +0.7 to -6.8 (Table 1), whereas the Neoproterozoic core within the inherited Ordovician grain gives the highest positive $\varepsilon \mathrm{Hf}_{(\mathrm{t})}$ value $(+5.0)$ of the analysed SCS zircons. Similarly to Hoyo de Pinares and Villacastín granites, a relict $\mathrm{Hf}$ isotopic heterogeneity is preserved from the inherited source(s) and in the melt, as deduced from the strong negative $\varepsilon \mathrm{Hf}_{(300)}$ value of -10.4 determined for the Ordovician inheritance 20.1 (Table 1).

\section{Discussion}

\subsection{Sources of the Variscan zircons}

The observed within-sample variation of $\mathrm{Hf}$ isotope composition in Variscan zircons from the SCS granite samples is always higher than the averaged analytical uncertainties on reference zircons $( \pm 1.5$ $\varepsilon$ units). Nevertheless, the heterogeneity of 2 to $5 \varepsilon \mathrm{Hf}$ units found in the SCS granites is significantly lower than the variation of up to 14 $\varepsilon \mathrm{Hf}$ units that have been observed in samples of Variscan S-type granites from northern Portugal (Teixeira et al., 2011). Significant Hf isotope heterogeneity within a single sample can only be reconciled by the operation of open system processes. To evaluate these processes, it is important to deduce the polarity of $\mathrm{Hf}$ isotope variation during zircon growth. This can be achieved by examination of zircon intracrystal isotope zoning rends and by pairing the isotope variation with $\mathrm{Th} / \mathrm{U}$ ratios, as a proxy for the degree of differentiation (e.g. Kemp et al., 2007). Th/ $\mathrm{U}$ ratios in the studied zircons typically decrease from core to rim (Orejana et al., 2012), and the $\varepsilon \mathrm{Hf}_{(\mathrm{t})}$ values of the zircons mostly decrease with $\mathrm{Th} / \mathrm{U}$ (Fig. 5). This progressive reduction in the $\varepsilon \mathrm{Hf}_{(\mathrm{t})}$ ratio during the magmatic evolution could be induced by the addition of an unradiogenic (crust-like) component. Only one reversely zoned zircon from the Navas del Marqués granite (Fig. 5) indicates an episodic input from a more isotopically primitive magmatic component recorded in its higher $\varepsilon \mathrm{Hf}_{(\mathrm{t})}$ value. The variable Hf isotope composition of the SCS granites reflects an isotopic heterogeneity that has not been erased during pluton assembly, and suggests a mixing of melt batches from different crustal sources, bearing in mind the absence of positive $\varepsilon \mathrm{Hf}_{(\mathrm{t})}$ values in the granite range. The large isotopic heterogeneity observed in the Navas del Marques ( $5 \varepsilon \mathrm{Hf}$ units) and Alpedrete granites ( $4 \mathrm{\varepsilon Hf}$ units) could be due to melting a much larger, and therefore potentially isotopically more heterogeneous, volume or material. Inefficient mixing in those granites, in contrast to more efficient mixing in the isotopically more homogeneous Hoyo de Pinares, Villacastin and Atalaya Real granites, may have also played a role.

The origin of the SCS Variscan granites has been related to melting of the lower crust on the basis of bulk geochemistry and $\mathrm{Sr}-\mathrm{Nd}-\mathrm{O}-\mathrm{Pb}$ isotope composition of deep-seated granulitic xenoliths (Villaseca and Herreros, 2000; Villaseca et al., 1999, 2009). Recent studies based on $\mathrm{U}-\mathrm{Pb}$ zircon ages in these SCS granulites reinforces this idea, showing an abundant population of metamorphic zircons formed in the range 320-283 Ma, clearly overlapping the timing of the SCS batholith construction (Fernández-Suárez et al., 2006; Orejana et al., 2011). The initial $\varepsilon H f$ composition in the SCS granites is restricted to the negative range of -1.2 to -5.8 , which is included within the wider isotopic range found in the SCS lower crustal granulite xenoliths ( +4.1 to -20.1 , Villaseca et al., 2011b) (Figs. 4 and 6). When combining whole-rock $\varepsilon N \mathrm{Nd}$ with $\varepsilon \mathrm{Hf}$ of zircons, there is a good overlap between SCS granites and the meta-igneous xenoliths from the SCS lower crust, and also with the outcropping Ordovician orthogneisses (Fig. 6). The absence of published Hf isotope data for SCS metasediments precludes a direct comparison with our data. However, previously published $\varepsilon \mathrm{Nd}$ values for those metasedimentary rocks allow to estimate equivalent $\varepsilon \mathrm{Hf}$ values using the terrestrial array Hf-Nd correlation $(\varepsilon \mathrm{Hf}=\varepsilon \mathrm{Nd} * 1.36+3)$ of Vervoort et al. (1999). Using the $\varepsilon \mathrm{Nd}_{300}$ values of Villaseca et al. (1998) $(\varepsilon \mathrm{Nd}=$ -9.1 to -12.5 ) an equivalent $\varepsilon \mathrm{Hf}$ range of -9.4 to -14.0 could be estimated. This $\varepsilon \mathrm{Hf}$ range plot towards the continental crustal end of the terrestrial line depicted in Fig. 6, towards much less radiogenic compositional fields than that defined for the SCS granites. Moreover, when comparing $\mathrm{U}-\mathrm{Pb}$ geochronological data of the studied SCS granites with those from the thick metasedimentary sequences of the southern Central Iberian Zone (the so called Schist Greywacke Formation, e.g. Ugidos et al., 2010, and references therein) significant 
Table 1

I.11-Hf isotope data of zircons from SCS granites

\begin{tabular}{|c|c|c|c|c|c|c|c|c|c|c|c|}
\hline Sample & $\mathrm{Th} / \mathrm{U}$ & 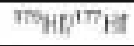 & $2 S E$ & 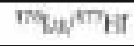 & 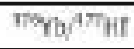 & Age (Ma) & 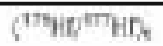 & $81 \mathrm{t}$ & $2 \mathrm{SE}$ & ToM & $T_{\text {tent2 }}$ \\
\hline \multicolumn{12}{|c|}{ Hoyo de Pinares granite (M21) } \\
\hline 2.1 & 0.21 & 0.282454 & 0.000009 & 0.00154 & 0.0620 & 299 & 0.282445 & -5.0 & 0.3 & 1.15 & 1.64 \\
\hline 3.1 & 0.52 & 0.282466 & 0.000009 & 0.00142 & 0.0636 & 299 & 0.282458 & -4.5 & 0.3 & 1.12 & 1.61 \\
\hline 4.1 & 0.20 & 0.282485 & 0.000011 & 0.00158 & 0.0754 & 299 & 0.282476 & -3.9 & 0.4 & 1.10 & 1.57 \\
\hline 6.1 & 0.79 & 0.282516 & 0.000007 & 0.00115 & 0.0571 & 299 & 0.282509 & -2.7 & 0.3 & 1.05 & 1.49 \\
\hline $7.1 \mathrm{r}$ & 0.14 & 0.282437 & 0.000008 & 0.00144 & 0.0661 & 299 & 0.282429 & -5.6 & 0.3 & 1.17 & 1.67 \\
\hline $7.2 \mathrm{c}$ & 0.45 & 0.282178 & 0.000011 & 0.00087 & 0.0400 & 828 & 0.282164 & -3.2 & 0.4 & 1.51 & 1.94 \\
\hline $8.1 \mathrm{c}$ & 0.69 & 0.282488 & 0.000010 & 0.00139 & 0.0676 & 299 & 0.282480 & -3.8 & 0.4 & 1.09 & 1.56 \\
\hline $8.2 \mathrm{r}$ & 0.29 & 0.282468 & 0.000007 & 0.00142 & 0.0675 & 299 & 0.282460 & -4.5 & 0.3 & 1.12 & 1.60 \\
\hline 9.1 & 0.17 & 0.282478 & 0.000007 & 0.00131 & 0.0619 & 299 & 0.282471 & -4.1 & 0.2 & 1.10 & 1.58 \\
\hline 11.1 & 0.32 & 0.282446 & 0.000010 & 0.00205 & 0.0919 & 299 & 0.282435 & -5.4 & 0.4 & 1.17 & 1.66 \\
\hline 12.1 & 0.69 & 0.282524 & 0.000011 & 0.00191 & 0.1006 & 299 & 0.282513 & -2.6 & 0.4 & 1.06 & 1.48 \\
\hline $13.1 \mathrm{c}$ & 0.53 & 0.282380 & 0.000011 & 0.00059 & 0.0299 & 638 & 0.282373 & -0.1 & 0.4 & 1.22 & 1.59 \\
\hline $18.1 \mathrm{c}$ & 0.52 & 0.282300 & 0.000006 & 0.00121 & 0.0588 & 619 & 0.282286 & -3.6 & 0.2 & 1.35 & 1.80 \\
\hline \multicolumn{12}{|c|}{ Alpedrete granite $(Y-76)$} \\
\hline 1.1 & 0.07 & 0.282447 & 0.000007 & 0.00137 & 0.0631 & 302 & 0.282439 & -5.1 & 0.3 & 1.15 & 1.65 \\
\hline 2.2 & 0.38 & 0.282458 & 0.000009 & 0.00127 & 0.0590 & 302 & 0.282451 & -4.7 & 0.3 & 1.13 & 1.62 \\
\hline 3.1 & 0.19 & 0.282433 & 0.000008 & 0.00198 & 0.0983 & 302 & 0.282422 & -5.8 & 0.3 & 1.19 & 1.69 \\
\hline 4.1 & 0.28 & 0.282490 & 0.000006 & 0.00110 & 0.0509 & 302 & 0.282484 & -3.6 & 0.2 & 1.08 & 1.55 \\
\hline 5.1 & 0.27 & 0.282504 & 0.000007 & 0.00147 & 0.0707 & 302 & 0.282496 & -3.1 & 0.3 & 1.07 & 1.52 \\
\hline 6.1 & 0.31 & 0.282496 & 0.000010 & 0.00122 & 0.0624 & 302 & 0.282489 & -3.4 & 0.3 & 1.08 & 1.54 \\
\hline $7.2 \mathrm{c}$ & 0.34 & 0.282528 & 0.000007 & 0.00100 & 0.0486 & 302 & 0.282522 & -2.2 & 0.2 & 1.03 & 1.46 \\
\hline $8.1 \mathrm{c}$ & 0.21 & 0.282466 & 0.000009 & 0.00015 & 0.0089 & 302 & 0.282465 & -4.2 & 0.3 & 1.09 & 1.59 \\
\hline $9.1 \mathrm{c}$ & 0.23 & 0.282467 & 0.000007 & 0.00011 & 0.0073 & 302 & 0.282466 & -4.2 & 0.2 & 1.09 & 1.59 \\
\hline $12.1 \mathrm{c}$ & 0.07 & 0.282455 & 0.000009 & 0.00170 & 0.0844 & 302 & 0.282445 & -4.9 & 0.3 & 1.15 & 1.63 \\
\hline $16.1 \mathrm{c}$ & 1.03 & 0.282478 & 0.000010 & 0.00221 & 0.1094 & 302 & 0.282466 & -4.2 & 0.3 & 1.13 & 1.59 \\
\hline $17.1 \mathrm{c}$ & 0.16 & 0.282482 & 0.000010 & 0.00124 & 0.0590 & 592 & 0.282468 & 2.3 & 0.3 & 1.10 & 1.40 \\
\hline L10 C & 0.24 & 0.282539 & 0.00001 & 0.00110 & 0.0350 & 302 & 0.282533 & -1.8 & 0.7 & 1.01 & 1.44 \\
\hline L3 C & 0.81 & 0.282471 & 0.000018 & 0.00167 & 0.0497 & 302 & 0.282462 & -4.3 & 0.6 & 1.13 & 1.60 \\
\hline $1 \mathrm{Ac}$ & 0.63 & 0.282460 & 0.000021 & 0.00120 & 0.0370 & 302 & 0.282453 & -4.6 & 0.7 & 1.13 & 1.62 \\
\hline L7 C & 0.38 & 0.282526 & 0.000024 & 0.00227 & 0.0684 & 581 & 0.282501 & 3.2 & 0.8 & 1.06 & 1.33 \\
\hline \multicolumn{12}{|c|}{ Villacustín granite $(Y-24)$} \\
\hline 1.1 & 0.26 & 0.282490 & 0.000005 & 0.00161 & 0.0796 & 301 & 0.282481 & -3.7 & 0.2 & 1.10 & 1.55 \\
\hline 2.1 & 0.05 & 0.282424 & 0.000008 & 0.00215 & 0.1010 & 479 & 0.282405 & -2.5 & 0.3 & 1.21 & 1.62 \\
\hline $5.2 \mathrm{c}$ & 0.43 & 0.282479 & 0.000009 & 0.00192 & 0.0972 & 301 & 0.282468 & -4.1 & 0.3 & 1.12 & 1.58 \\
\hline $7.1 \mathrm{c}$ & 0.28 & 0.282509 & 0.000007 & 0.00078 & 0.0374 & 301 & 0.282505 & -2.8 & 0.3 & 1.05 & 1.50 \\
\hline 9.1 & 0.30 & 0.282472 & 0.000009 & 0.00152 & 0.0772 & 301 & 0.282463 & -4.3 & 0.3 & 1.12 & 1.59 \\
\hline $13.1 \mathrm{c}$ & 0.34 & 0.282510 & 0.000008 & 0.00093 & 0.0452 & 301 & 0.282505 & -2.8 & 0.3 & 1.05 & 1.50 \\
\hline $13.2 \mathrm{r}$ & 0.23 & 0.282522 & 0.000009 & 0.00146 & 0.0701 & 301 & 0.282514 & -2.5 & 0.3 & 1.05 & 1.48 \\
\hline 15.1 & 0.18 & 0.282507 & 0.000009 & 0.0011 & 0.0554 & 301 & 0.282500 & -3.0 & 0.3 & 1.06 & 1.51 \\
\hline $16.1 \mathrm{c}$ & 0.08 & 0.282400 & 0.000009 & 0.00278 & 0.1325 & 462 & 0.282376 & -3.9 & 0.3 & 1.26 & 1.69 \\
\hline $20.1 \mathrm{r}$ & 0.04 & 0.282108 & 0.000015 & 0.00093 & 0.0407 & 464 & 0.282100 & -13.6 & 0.5 & 1.61 & 2.30 \\
\hline $20.2 c$ & 0.57 & 0.281545 & 0.000014 & 0.00092 & 0.0407 & 1956 & 0.281511 & -1.0 & 0.5 & 2.39 & 2.67 \\
\hline 22.1 & 0.14 & 0.282479 & 0.000007 & 0.00159 & 0.0675 & 301 & 0.282470 & -4.1 & 0.3 & 1.11 & 1.58 \\
\hline \multicolumn{12}{|c|}{ Atalay Real granite (Y-78) } \\
\hline $2.2 \mathrm{c}$ & 0.20 & 0.282476 & 0.000007 & 0.00114 & 0.0555 & 306 & 0.282469 & -4.0 & 0.3 & 1.10 & 1.58 \\
\hline 3.1 & 0.36 & 0.282497 & 0.000011 & 0.00080 & 0.0394 & 306 & 0.282492 & -3.2 & 0.4 & 1.06 & 1.53 \\
\hline 4.1 & 0.40 & 0.282523 & 0.000010 & 0.00067 & 0.0330 & 306 & 0.282519 & -2.2 & 0.4 & 1.02 & 1.47 \\
\hline $6.1 \mathrm{r}$ & 0.34 & 0.282481 & 0.000015 & 0.00078 & 0.0380 & 306 & 0.282477 & -3.7 & 0.5 & 1.09 & 1.56 \\
\hline $6.2 \mathrm{c}$ & 0.61 & 0.282489 & 0.000009 & 0.00133 & 0.0671 & 306 & 0.282482 & -3.6 & 0.3 & 1.09 & 1.55 \\
\hline $7.1 \mathrm{c}$ & 0.35 & 0.282505 & 0.000009 & 0.00153 & 0.0776 & 306 & 0.282496 & -3.0 & 0.3 & 1.07 & 1.52 \\
\hline $7.2 \mathrm{r}$ & 0.08 & 0.282456 & 0.000012 & 0.00174 & 0.0810 & 306 & 0.282446 & -4.8 & 0.4 & 1.15 & 1.63 \\
\hline 9.1 & 0.21 & 0.282511 & 0.000006 & 0.00125 & 0.0624 & 306 & 0.282504 & -2.8 & 0.2 & 1.06 & 1.50 \\
\hline 10.1 & 0.24 & 0.282446 & 0.000010 & 0.00090 & 0.0460 & 306 & 0.282441 & -5.0 & 0.4 & 1.14 & 1.64 \\
\hline $13.1 \mathrm{c}$ & 0.73 & 0.282440 & 0.000008 & 0.00071 & 0.0336 & 306 & 0.282436 & -5.2 & 0.3 & 1.14 & 1.65 \\
\hline \multicolumn{12}{|c|}{ Navas del Marqués granite (M9) } \\
\hline $2.1 \mathrm{c}$ & 0.36 & 0.282431 & 0.000021 & 0.00198 & 0.0654 & 300 & 0.282420 & -5.9 & 0.7 & 1.19 & 1.69 \\
\hline $3.1 \mathrm{c}$ & 0.47 & 0.282519 & 0.000026 & 0.00182 & 0.0546 & 465 & 0.282503 & 0.7 & 0.9 & 1.06 & 1.40 \\
\hline $5.1 \mathrm{r}$ & 0.08 & 0.282375 & 0.000013 & 0.00183 & 0.0541 & 467 & 0.282359 & -4.3 & 0.5 & 1.27 & 1.73 \\
\hline $5.2 \mathrm{c}$ & 0.34 & 0.282578 & 0.000017 & 0.00143 & 0.0479 & 564 & 0.282563 & 5.0 & 0.6 & 0.97 & 1.21 \\
\hline 6.1 & 0.34 & 0.282505 & 0.00001 & 0.00142 & 0.0391 & 300 & 0.282497 & -3.1 & 0.7 & 1.07 & 1.52 \\
\hline $7.1 \mathrm{c}$ & 0.58 & 0.282525 & 0.000020 & 0.00133 & 0.0441 & 300 & 0.282517 & -2.4 & 0.7 & 1.04 & 1.47 \\
\hline $7.2 \mathrm{r}$ & 0.30 & 0.282559 & 0.000018 & 0.00112 & 0.0319 & 300 & 0.282553 & -1.2 & 0.6 & 0.98 & 1.39 \\
\hline 8.1 & 0.30 & 0.282558 & 0.000021 & 0.00128 & 0.0383 & 300 & 0.282551 & -1.2 & 0.7 & 0.99 & 1.40 \\
\hline 9.1 & 0.22 & 0.282526 & 0.000022 & 0.00110 & 0.0335 & 300 & 0.282520 & -2.3 & 0.8 & 1.03 & 1.47 \\
\hline 10.1 & 0.24 & 0.282513 & 0.000026 & 0.00131 & 0.0420 & 300 & 0.282506 & -2.8 & 0.9 & 1.05 & 1.50 \\
\hline 11.1 & 0.36 & 0.282513 & 0.000022 & 0.00148 & 0.0433 & 300 & 0.282505 & -2.9 & 0.8 & 1.06 & 1.50 \\
\hline 12.1 & 0.42 & 0.282494 & 0.000028 & 0.00207 & 0.0679 & 300 & 0.282482 & -3.7 & 1.0 & 1.10 & 1.55 \\
\hline $15.1 \mathrm{c}$ & 0.59 & 0.282498 & 0.000019 & 0.00115 & 0.0320 & 300 & 0.282492 & -3.3 & 0.7 & 1.07 & 1.53 \\
\hline $17.1 \mathrm{r}$ & 0.50 & 0.282459 & 0.000049 & 0.00117 & 0.0330 & 300 & 0.282452 & -4.7 & 1.7 & 1.13 & 1.62 \\
\hline $18.1 \mathrm{C}$ & 0.56 & 0.282507 & 0.000022 & 0.00107 & 0.0296 & 300 & 0.282501 & -3.0 & 0.8 & 1.06 & 1.51 \\
\hline
\end{tabular}




\begin{tabular}{|c|c|c|c|c|c|c|c|c|c|c|c|}
\hline Sample & $\mathrm{Th} / \mathrm{U}$ & ${ }^{27 \mathrm{Hif} / 27} \mathrm{HI}$ & 2SE & ${ }^{n x_{\text {Lu }}}{ }^{\prime \prime \prime}$ Hif & ${ }^{2 \pi} \mathrm{Y}_{\mathrm{b}}{ }^{2 T / 7} \mathrm{Ht}$ & Age (Ma) & $\left(^{1 \mathrm{~K}} \mathrm{Hif}^{175} \mathrm{HA}\right.$ & $\mathrm{ch}$ & $2 \mathrm{SE}$ & $T_{M M}$ & $T_{\text {int: }}$ \\
\hline $19.1 \mathrm{c}$ & 0.32 & 0.282460 & 0.000014 & 0.00103 & 0.0286 & 300 & 0.282454 & -4.7 & 0.5 & 1.12 & 1.61 \\
\hline $20.1 \mathrm{c}$ & 0.07 & 0.282306 & 0.000042 & 0.00257 & 0.0732 & 478 & 0.282283 & -6.8 & 1.5 & 1.39 & 1.89 \\
\hline
\end{tabular}

$\mathrm{c}=$ core, $\mathrm{r}=$ rim. No petrographical description refers to rim sectors. Identical spot numbers refer to the same zircon grain.

differences appear (Fig. 7). It is remarkable the absence of Mesoproterozoic inheritances in the SCS granites while this group of ages is an important population in $\mathrm{CIZ}$ metasediments. Also is noticeable the minor presence of ages in the range of 540 to $640 \mathrm{Ma}$ in the metasediments whereas this is an important group of inheritances in the SCS granites (Fig. 7). All this suggests that metasedimentary rocks have not been significantly involved in granite petrogenesis.

Some authors consider that mantle-derived magmas play a substantial role in the genesis of the Variscan granite magmatism in central Spain (e.g. Cas tro et al., 1999; Pinarelli and Rottura, 1995). The scarce SCS mafic intrusions are coeval with granite emplacement favouring hybridism between them (e.g. Scarrow et al., 2009; Villaseca et al., 2011a; Zeck et al., 2007b). Recent Lu-Hf data of zircons in gabbros from central Spain suggest their origin from an enriched Variscan subcontinental mantle with a positive initial $\varepsilon \mathrm{Hf}$ range of +1.5 to +6.9 (Villaseca et al., 2011a). The SCS granites lack positive initial $\varepsilon H f$ values in zircon, and their negative $\varepsilon \mathrm{Hf}$ and $\varepsilon N d$ values, which plot away from the SCS gabbros field (Fig. 6), reinforce the hypothesis of a minor mantle contribution for these slightly heterogeneous granitic magmas. As in other peraluminous granite suites, the limited magma mixing with basic melts does not appear to be a significant process affecting the chemical evolution of the granite magmas (Clemens, 2003). This is also in agreement with thermal models which suggest that granite magmatism in the SCS does not require a significant addition of heat from mantle sources due to the high internal radiogenic heat production of the SCS lithotypes and the factor of doubling the original crustal thickness during the Variscan collision (e.g. Bea et al., 2003; Villaseca et al., 2009).

It is also remarkable that the ranges of initial $\varepsilon \mathrm{Hf}$ in magmatic zircons of both SCS granite-types are almost identical: -1.9 to -5.8 in the S-types and -1.2 to -5.9 in the I-type granites (Table 1 ; Fig. 6 ). This uniform Hf-isotope composition of zircons from the SCS granites agrees well with the previously reported similarity in whole-rock Sr, $\mathrm{Nd}, \mathrm{O}$ and $\mathrm{Pb}$ isotopic signatures (Villaseca and Herreros, 2000; Villaseca et al., 1998, 2009). The resemblance in multiple isotopic signatures between S- and I-type granites in the SCS batholith is in accordance with their derivation from similar sources, while the variation in granite peraluminosity might be related to different partial melting conditions, an issue which deserves further study. In this respect, Clemens et al.

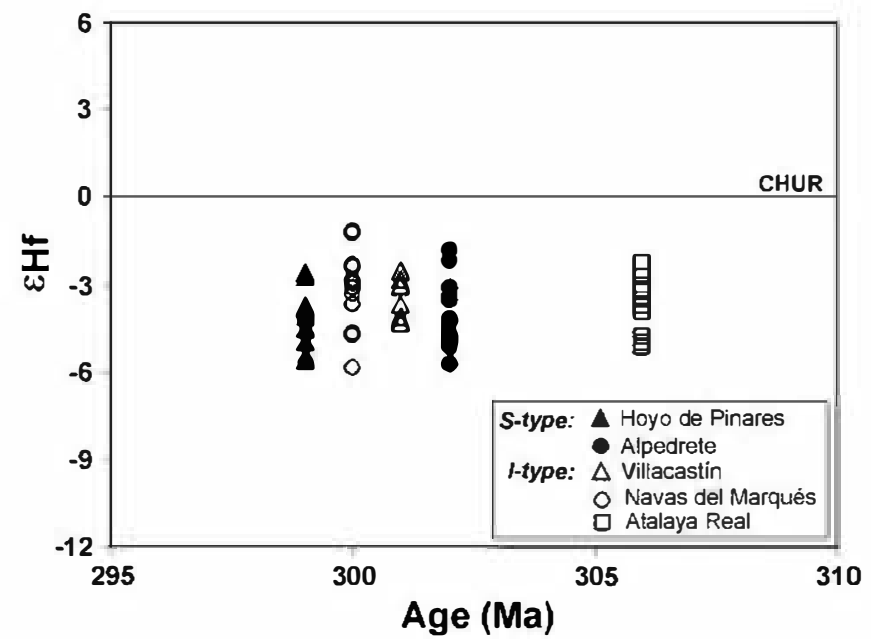

Fig. 3. Initial $\varepsilon \mathrm{Hf}$ values of individual Variscan zircons from SCS granites. The ages used to calculate the initials values are intrusive ages of each granite unit.
(2011) suggest that the S-I granite dichotomy merely reflects the nature of the peritectic minerals entrained by the ascending granite melts and not the composition of their sources that could be indeed very similar.

\subsection{Cons traints on the pre-Varis can zircons}

Pre-Variscan ages have been recorded in zircon cores or whole zircon grains from 4 of the analysed samples (Table 1). Two groups of ages have been distinguished (Orejana et al., 2012): 1) Ordovician analyses in I-type granites defining a restricted cluster of 462-479 Ma, and 2) inherited cores recording older Proterozoic ages (564-1956 Ma). The two I-type granite samples with Ordovician xenocrysts also show Neoproterozoic (564 Ma) and Palaeoproterozoic (1956 Ma) inheritances as discordant cores within those xenocrysts (Fig. 2C \#20; Fig. 2E \#5). S-type granites have only Neoproterozoic pre-Variscan cores (581$828 \mathrm{Ma}$ ) surrounded by magmatic Variscan rims. This contrast in inheritances suggests that distinct source rocks have been involved in the genesis of the two SCS granitic series. However, the previously discussed geochemical similarity between them ( $\mathrm{Sr}, \mathrm{Nd}, \mathrm{O}, \mathrm{Pb}, \mathrm{Hf}$ isotopes) implies that further explanation of this paradox will be needed.

An important Ordovician magmatic event has been identified in the Central Iberian Zone. U-Pb zircon dating in orthogneisses has yielded crystallisation ages from 496 to $464 \mathrm{Ma}$ (Castiñeiras et al., 2008; Montero et al., 2009; Valverde-Vaquero and Dunning, 2000; Zeck et al., 2007a). The presence of Ordovician ages in zircon grains from SCS Itype granites suggests that their source materials could be Ordovician plutonic rocks metamorphosed during the Variscan collision at lower crustal levels (Orejana et al., 2012). Moreover, $\varepsilon \mathrm{Hf}_{(\mathrm{t})}$ values of Ordovician zircons in SCS I-type granites $(+0.7$ to -13.6 , Table 1$)$ are very similar to the Hf isotopic range described by Villaseca et al. (2011b) for outcropping SCS migmatised orthogneisses: +2.4 to -12.5 , reinforcing this genetic relationships with metaigneous sources.

The SCS granites show scarce and dispersed inherited zircon populations of Neoproterozoic ages. They mainly spread from 638 to

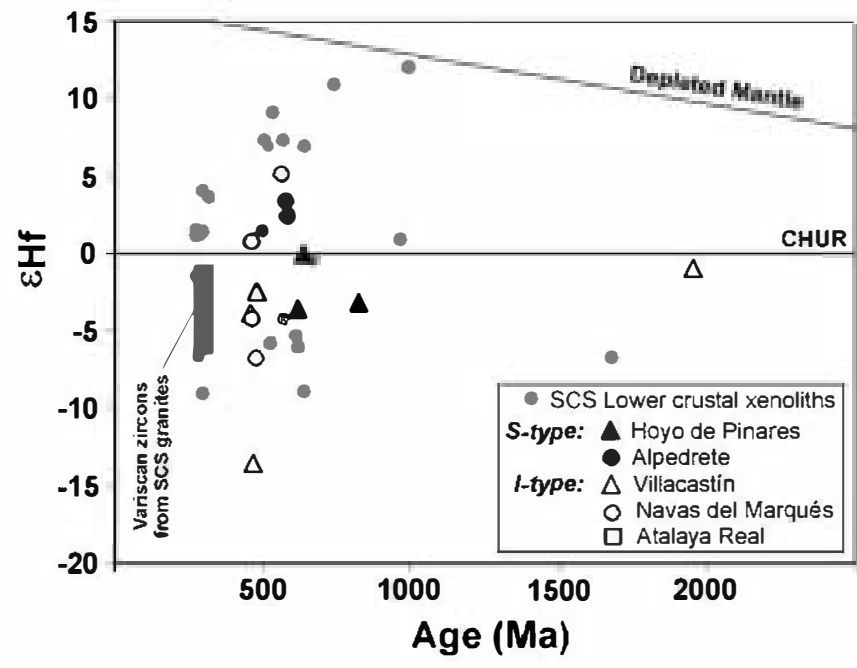

Fig. 4. $\varepsilon \mathrm{Hf}_{\mathrm{t}}$ values of individual pre-Variscan zircons from SCS granites. The ages used to calculate the initials values are those from Table 1. Values from granulite xenoliths from the SCS lower crust (samples U145 and U152) are taken from Villaseca et al. (2011b). 


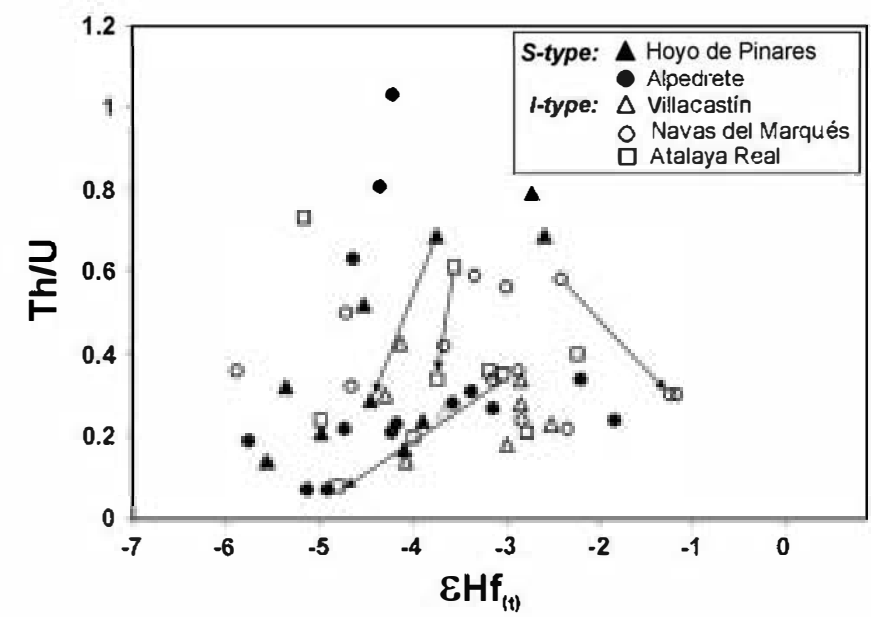

Fig. 5. Hf isotopic composition of zircons from each granite unit plotted against the Th/U ratio measured for the same part of the crystal. Arrows show the core-to-rim zoning for individual zircons.

$564 \mathrm{Ma}$ (Table 1). The two Proterozoic zircon cores included in Ordovician xenocrysts from SCS I-type granites must represent inheritances from the orthogneiss protolith. The abundance of inherited zircon cores is a main characteristic of the Clz Ordovician metaigneous rocks (Bea et al., 2007). A recent paper by Fernández-Suárez et al. (2011) highlights the overwhelming predominance of inherited ages younger than $\sim 650 \mathrm{Ma}$ in many granitic intrusions from the Iberian Variscan Belt. These authors also suggest that the Variscan granites are mainly related to Cambro-Ordovician metaigneous protoliths, and that influence of Neoproterozoic components might derive from metasedimentary contamination. Nevertheless, as we discussed above the absence of Mesoproterozoic inheritances in the SCS granites makes it difficult to suggest the involvement of the $\mathrm{CIZ}$ metasediments which have a significant zircon population within this age range (GutiérrezAlonso et al., 2003; Teixeira et al., 2011) (Fig. 7).

A remarkable feature of the inherited Neoproterozoic zircons in the SCS granites is their positive $\varepsilon \mathrm{Hf}_{(\mathrm{t})}$ values $(+2.3$ to +5.0$)$ shown in the 564-592 Ma population, that suggests a possible juvenile addition at that time. This probable Neoproterozoic mantle addition is also recorded in metaigneous granulite facies rocks of central Spain, either from outcropping metamorphic terranes or from lower crustal levels (Villaseca et al., 2011b). The presence of inherited Neoproterozoic zircons in the SCS granites displaying a juvenile Hf-isotope

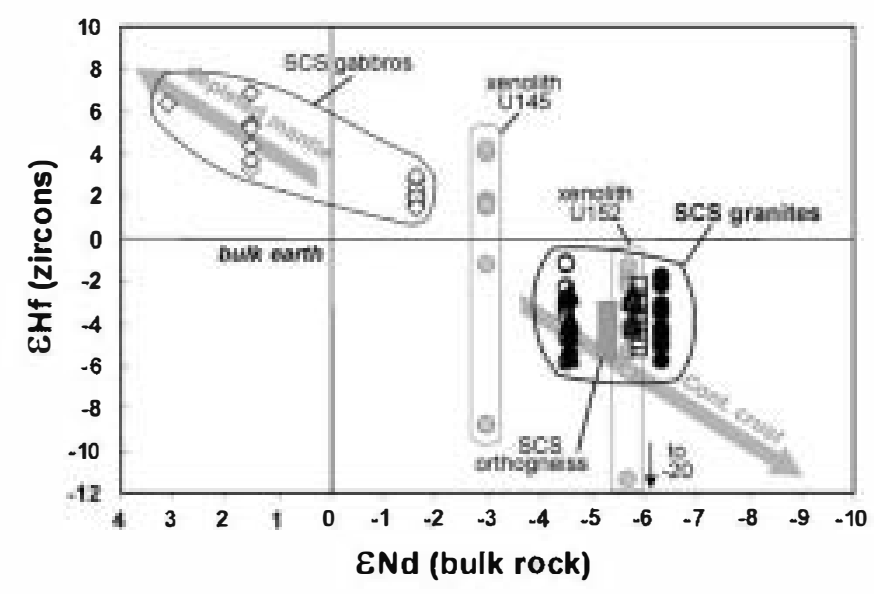

Fig. 6. The Hf isotope composition of Variscan zircons from samples of each granite unit as a function of whole-rock Nd composition at the time of crystallisation. The data for SCS gabbros are from Ore jana et al. (2009) and Villaseca et al. (2011a), whereas data from meta-igneous protoliths are those from Villaseca et al. (2011b). Terrestrial array (thick grey line) taken from Vervoort et al. (1999).

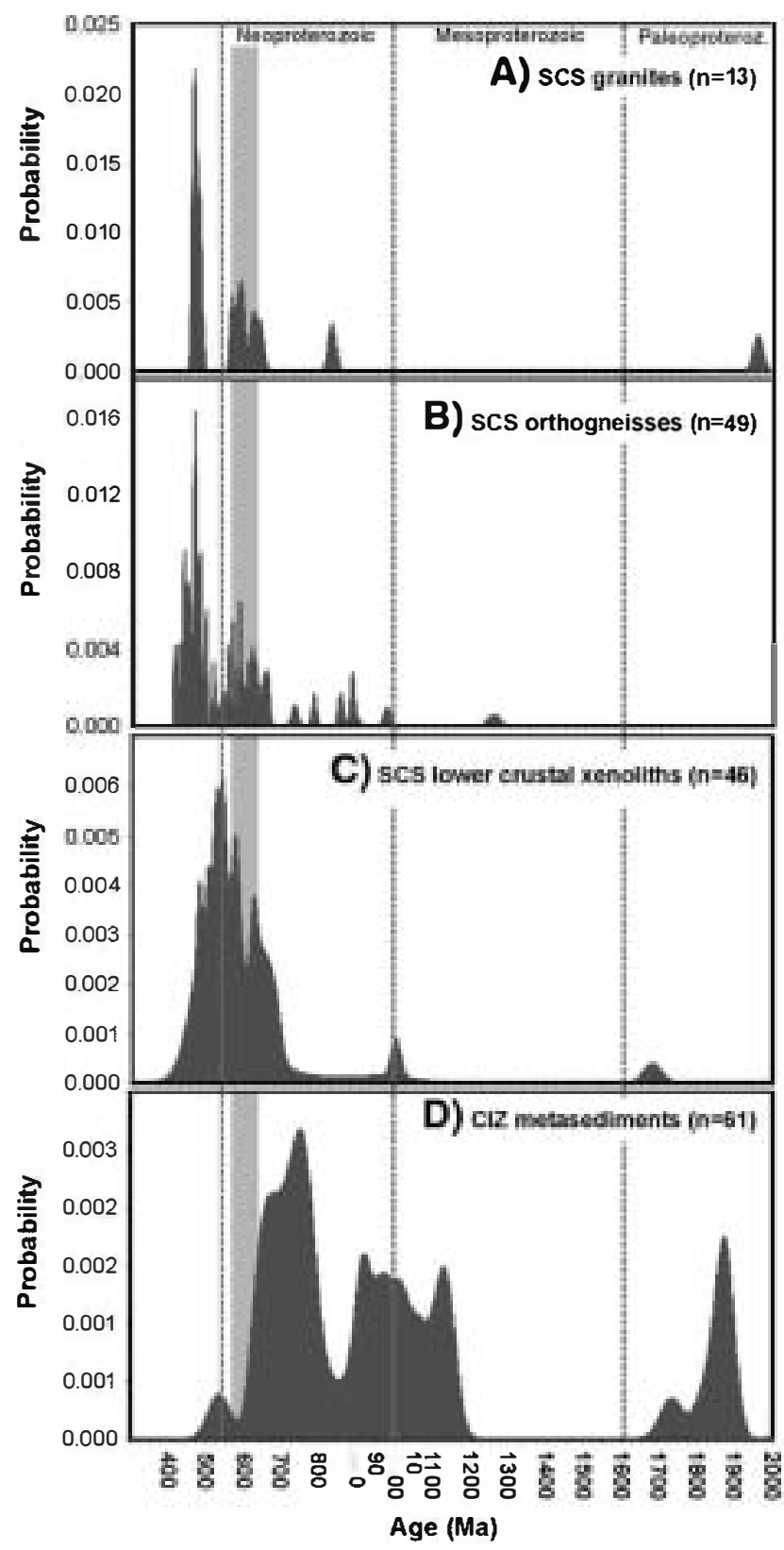

Fig. 7. Relative probability plots for pre-Variscan zircon U-Pb ages from (a) SCS granites (Orejana et al., 2012), (b) SCS orthogneisses (samples from Sotosalbos, Castiñeiras et al., 2008), (c) granulite xenoliths from the SCS lower crust (Ore jana et al., 2011), (d) CIZ metasediments from the Schist-Greywacke Formation (samples 2D-1 and ZD-2 from Gutierrez-Alonso et al. (2003), and sample of the Sabugal area from Teixeira et al. (2011))

composition suggests that the source of magma was most likely heterogeneous metaigneous protoliths and that it may have gone through multiple events of crustal reworking.

Hf-isotope composition of other Neo-to-Paleoproterozoic inherited zircons in SCS granites overlap with that of the metaigneous granulites from the lower crust (Villaseca et al., 2011b). Hf-isotope data corroborates the important role of metaigneous protoliths granulitised in the SCS lower crust in the genesis of the huge epizonal peraluminous granite batholith of central Spain. Moreover, the low percentage and variability in the Ordovician zircon population (462$494 \mathrm{Ma}$ ) found in lower crustal metaigneous granulite xenoliths (from 0 to 9\%, Fernández-Suárez et al., 2006; Orejana et al., 2011) (Fig. 7) could explain the differences in age inheritances shown by the studied S- and I-type SCS granites. 


\section{Conclusions}

Zircon from five granitic intrusions from eastern Spanish Central System have been analysed in order to characterise their Hf-isotope composition to evaluate the source nature and provide additional constraints for the processes operating during magma crystallisation. In some granites (Hoyo de Pinares, Villacastín, Atalaya Real) Hfisotope variation in their Variscan zircons were almost achieved under closed-system conditions during crystallisation. Significant isotopic heterogeneities suggest mixing of different magma batches during pluton assembly. The Hf-isotope signatures of Variscan from SCS granites in the relatively restricted range of -1.2 to -5.8 values suggest metaigneous lower crustal sources with very minor juvenile mantle contribution.

Four of the granite samples have a small number of pre-Variscan zircon cores. Two I-type intrusions display Ordovician inherited grains which closely match the age of the widespread late Palaeozoic magmatism outcropping from northwest to central Spain. Thus, Itype plutons are likely derived from melting of Ordovician metaigneous protoliths at lower crustal levels. The sampled S-type granites display a scarce population of inherited Neoproterozoic zircons which do not allow a straightforward interpretation regarding the nature of their protolith. Nevertheless, the paucity of inherited zircons and the relatively narrow Hf-isotope composition of the SCS granites suggest that these rocks were derived from similar metaigneous source rocks rather than from metasedimentary protoliths. The similarity between the Hf-isotope composition of granite zircons and those from metaigneous xenoliths suggests their derivation from the lower crustal levels. Thus, the Variscan magmatism in central Spain is dominantly a crustal reworking event.

\section{Acknowledgements}

This work is included in the objectives of, and supported by, the CGL-2008-05952 and CGL2011-23560 projects of the Ministerio de Educación y Ciencia of Spain and the GR35/10A project of the 910492 UCM group. CV thanks the opportunity to undertake the analytical work in the Geochemical Analysis unit at GEMOC, at Macquarie University. We acknowledge Norman Pearson and Rosanna Murphy for their assistance with the I.A-ICPMS analyses. Suggestions by the Editor, Michael Flowerdew and an anonymous reviewer have greatly improved the quality of the manuscript. This is contribution 30 from the ARC Centre of Excellence for Core to Crust Fluid Systems (http:// www.ccfs.mq.edu.au) and 799 in the GEMOC Key Centre (http:// www.gemoc.mq.edu.au).

\section{References}

Andersen, T., Griffin, W.L., Pearson, N.J., 2002. Crustal evolution in the SW part of the Baltic Shield: the Hf isotope evidence. Journal of Petrology 43, 1725-1747.

Appleby, S.K., Gillespie, M.R., Graham, C.M., Hinton, RW., Oliver, G.J.H., Kelly, N.M. EIMF, 2010. Do S-type granites commonly sampled infracrustal sources? New results from an integrated $\mathrm{O}, \mathrm{U}-\mathrm{Pb}$ and $\mathrm{Hf}$ isotope study of zircon. Contributions to Mineralogy and Petrology 160, 115-132.

Arndt, N.T., Goldstein, S.L., 1987. Use and abuse of crust-formation ages. Geology 15 , 893-895.

Barbero, L., Villaseca, C., 2000. Eclogite facies relics in metabasites from the Sierra de Guadarrama (Spanish Central System): $\boldsymbol{P}-T$ estimations and implications for the Hercynian evolution. Mineralogical Magazine 64, 815-836.

Bea, F., 2010. Crystallization dynamics of granite magma chambers in the absence of regional stress: multiphysics modelling with natural examples. Journal of Petrology 51, 1541-1569.

Bea, F., Montero, P., Molina, J.F., 1999. Mafic precursors, peral uminous granitoids, and late lamprophyres in the Avila batholith; a model for the generation of Variscan batholiths in Iberia. Journal of Geology 107, 399-419.

Bea, F., Montero, P., Zinger, T., 2003. The nature, origin, and thermal influence of the granite source layer of Central Iberia. Journal of Geology 111, 579-595.

Bea, F., Montero, P., González-Iodeiro, F., Talavera, C., Molina, J.F., Scarrow, J.H. Whitehouse, M.J., Zinger, T., 2006. Zircon thermometry and U-Pb ion-microprobe dating of the gabbros and associated migmatites of the Variscan Toledo anatectic complex, central Iberia. Journal of the Geological Society of Iondon 163, 847-855.
Bea, F., Montero, P., González-Lodeiro, F., Talavera, C., 2007. Zircon inheritance reveals exceptionally fast crustal magma generation processes in Central Iberia Turing the Cambro-Ordovician. Journal of Petrology 48, 2327-2339.

Bea, F., Pesquera, A., Montero, P., Torres-Ruiz, J., Gil-Crespo, P.P., 2009. Tourmaline ${ }^{4 \bullet} \mathrm{Ar} /{ }^{39} \mathrm{Ar}$ chronology of tourmaline-rich mcks from Central Iberia dates the main Variscan deformation phases. Geologica Acta 7, 399-412.

Bouvier, A., Vervoot, J.D., Patchett, P.J., 2008. The Lu-Hf and Sm-Nd isotopic composition of CHUR: constraints from unequilibrated chondrites and implications for the bulk composition of terrestrial planets. Earth and Planetary Science Ietters 273, 48-57.

Castiñeiras, P., Villaseca, C., Barbero, L., Martín Romera, C., 2008. SHRIMP U-Pb zircon dating of anatexis in high-grade migmatite complexes of Central Spain: implications in the Hercy nian evolution of Central Iberia. International Journal of Earth Scienœes 97 35-50.

Castro, A., Patiño Douce, A.E., Corretgé, L.G., De la Rosa,J.D., EI-Biad, M. El-Hmidi, H., 1999 Origin of peraluminous granites and granodiorites, Iberian Massif, Spain. An experimental test to granite petrogenesis. Contributions to Mineralogy and Petrolog $135,255-276$.

Chappell, B.W., White, A.J.R., 1974. Two contrasting granite types. Pacific Geology 8 , 173-174.

Clemens, J.D., 2003. S-type granitic magmas: petrogenetic issues, models and evidence. Earth-Science Reviews 61, 1-18.

Clemens, J.D., Stevens, G., Farina, F., 2011. The enigmatic sources of I-type granites: the peritectic connexion. Lithos $126,174-181$

Díaz-Alvarado, J., Castro, A, Fernández, C., Moreno-Ventas, I., 2011. Assessing bulk assimilation in cordierite-bearing granitoids from the Central System Batholith, Spain; experimental, geochemical and geochronological onstraints. Journal of Petrology 52 , 223-256.

Díez Balda, MA., García Casquero, J.L., Monteserín López, V., Nozal Martín, F., Pardo Alonso, M.V., Robles Casas, R, 1990. Cizallamientos subverticales posteriores a la segunda fase de deformación Hercínica al sur de Salamanca (Zona centro Iberica). Revista de la Sociedad Geológica de España 3, 117-125.

Escuder-Viruete, J., Hernáiz, P.P., Valverde-Vaquero, P., Rodríguez, R., Dunning, G 1998. Variscan syncollisional extension in the Iberian Massif: structural, metamorphic and geochronological evidence from the Somosierra sector of the Sierra de Guadarrama (Central Iberian Zone, Spain). Tectonophysics 290, 87-109.

Fernández-Suárez, J., Arenas, R., Jeff ries, T.E., Whitehouse, M.J., V illaseca, C., 2006. A U$\mathrm{Pb}$ study of zircons from a lower crustal granulite xenolith of the Spanish Central System: a record of Iberian lithospheric evolution from the Neoproterozoic to the Triassic. Journal of Geology 114, 471-483.

Fernández-Suárez, J., Gutiêrrez-Alonso, G., Johnston, S.T., Jeffries, T.E., Pastor-Galán, D. Jenner, G.A. Murphy, J.B., 2011. Iberian late-Variscan granitoids: some considerations on crustal sources and the significance of "mantle extraction ages". lithos 123, 121-132.

Flowerdew, M.J., Millar, I.L., Vaughan, A.P.M., Horstwood, M.S.A., Fanning, C.M., 2006 The source of granite gneisses and migmatites in the Antarctic Peninsula: a combined U-Pb SHRIMP and laser ablation Hf isotope study of complex zircons. Contributions to Mineralogy and Petrology 151, 751-768.

Griffin, W.L., Wang, X., Jackson, S.E., Pearson, N.J., O'Reilly, S.Y., Xu, X., Zhou, X., 2002 Zircon chemistry and magma mixing, SE China: in situ analysis of Hf isotopes, Tonglu and Pingtan igneous complexes. Lithos 61, 237-269.

Griffin, W.L., Belousova, E., Shee, S.R., Pearson, N.J., O'Reilly, S.Y., 2004 Archean crusta evolution in the northern Yilgarn Craton: $\mathrm{U}-\mathrm{Pb}$ and Hf-isotope evidence from detrital zircons. Precambrian Research 131, 231-282.

Gutiérrez-Alonso, G., Fernández-Suárez, J., Jeffries, T.E., Jenner, G.A., Tubrett, M.N., Cox R., Jackson, S.E., 2003. Terrane accretion and dispersal in the northern Gondwana margin. An early Paleozoic analogue of a long-lived active margin. Tectonophysics 365, 221-232.

Ibarrola, E., Villaseca, C., Vialette, Y., Fiister, J.M., Navidad, M., Peinado, M., Casquet, C. 1987. Dating of Hercynian granites in the Sierra de Guadarrama (Spanish Centra System). In: Bea, F., Carnicero, A., Gonzalo, J.C., López Plaza, M., Rodríguez Alonso, M.D. (Eds.), Geología de los granitoides y rocas asociadas del Macizo Hespérico. Rueda, Madrid, pp. 377-383.

Iizuka, T., Komiya, T., Rino, S., Maruyama, S., Hirata, T., 2010. Detrital zircon evidence for Hf isotopic evolution of granitoid crust and continental growth. Geochimica et Cosmochimica Acta 74, 2450-2472

Kemp, A.I.S., Hawkesworth, C.J., Foster, G.L., Paterson, B.A., Woodhead, J.D., Hergt, J.M Gray, C.M., Whitehouse, M.J., 2007. Magmatic and crustal differentiation his tory of granitic rocks from Hf-O isotopes in zircon. Science 315, 980-983.

Kurhila, M., Andersen, T., Rämo, O.T., 2010. Diverse sources of crustal granitic magma: Li1-Hf isotope data on zircon in three Paleoproterozoic leucogranites of southern Finland Lithos 115, 263-271.

Macaya, J., González-Lodeiro, F., Martínez-Catalán, J.R., Álvarez, F., 1991. Continuous deformation, ductile thrusting and backfolding of cover and basement in the Sierra de Guadarrama, Hercynian orogen of central Spain. Tectonophysics 191, 291-30s.

Matte, P., 2001. The Variscan collage and orogeny $(480 \pm 290 \mathrm{Ma})$ and the tectonic definition of the Armorica microplate: a review. Terra Nova 13, 122-128.

Montero, P., Bea, F., Zinger, T.F., Scarrow, J.H., Molina, J.F., Whitehouse, M. J., 2004. 55 Million years of continuous anatexis in Central Iberia: single zircon dating of the Peña Negra complex. Journal of the Geological Society of London 161, 255-264.

Montero, P., Talavera, C., Bea, F., González-Lodeiro, F., Whitehouse, M.J., 2009. Zircon geochronology of the Ollo de Sapo formation and the age of the CambroOrdovician rifting in Iberia. Journal of Geology 117, 174-191.

Moreno-Ventas, I., Rogers, G., Castro, A., 1995. The role of hybridization in the genes is of the Hercynian granitoids in the Gredos Massif, Spain: inferences from Sr-Nd isotopes. Contributions to Mineralogy and Petrology 120, 137-149. 
Ore jana, D., Villaseca, C., Pérez-Soba, C., López-García, J.A, Billström, K., 2009. The Variscan gabbros from the Spanish Central System: a case for crustal recycling in the sub-continental lithospheric mantle? Lithos 110, 262-276.

Ore jana, D., Villaseca, C, Armstrong, R.A. Jeff ries, T.E., 2011. Geochronology and trace element chemistry of zircon and garnet from granulite xenoliths: constraints on the tectonothermal evolution of the lower crust under central Spain. Lithos 124 $103-116$.

Orejana, D., Villaseca, C, Valverde-Vaquero, P, Belousova, E.A, Armstrong, R.A, 2012. U$\mathrm{Pb}$ geochronology and zircon composition of late Variscan S- and I-type granitoids from the Spanish Central System. Intemational Joumal of Earth Sciences. doi:10.1007/ s00531-012-0750-y

Pinarelli, L., Rottura, A., 1995. Sr and Nd isotopic study and Rb-Sr geochronology of the Bê jar granites, Iberian Massif, Spain. European Journal of Mineralogy 7, 577-589.

Scarrow, J.H., Molina, J.F., Bea, F., Montero, P., 2009. Within-plate calc-alkaline rocks: insights from alkaline mafic magma-peraluminous crustal melt hybrid appinites of the Central Iberian Variscan continental collision. Lithos 110, 50-64.

Scherer, E.E., Münker, C, Mezger, K., 2001. Calibration of the lutetium-hafnium clock. Science 293, 683-687

Shaw, S.E., Flood, R.H., Pearson, N.J., 2011. The New England batholith of eastern Australia: evidence of silicic magma mixing from zircon ${ }^{176} \mathrm{Hf} /{ }^{177} \mathrm{Hf}$ ratios. Lithos 126, 115-126.

Solá, A.R., Williams, I.S., Neiva, A.M.R., Ribeiro, M.L., 2009. U-Th-Pb SHRIMP ages and oxygen isotope composition of zircon from two contrasting late Variscan granitoids, Nisa-Alburquerque batholith,SW Iberian Massif: petrologic and regional implications. lithos 111, 156-167.

Teixeira, R.J.S., Neiva, A.M.R., Silva, P.B., Gomes, M.E.P, Andersen, T., Ramos, J.M.F., 2011. Combined U-Pb geochronology and I.1-Hf isotope systematics by IAMICPMS of zircons from granites and metasedimentary rocks of Carrazeda de Ansiaes and Sabugal areas, Portugal, to constrain granite sources. Lithos 125 , 321-334.

Ugidos, J.M., Recio, C, 1993. Origin of cordierite-bearing granites by assimilation in the Central Iberian Zone, Spain. Chemical Geology 103, 27-43

Ugidos,J.M., Sánchez-Santos,J.M., Barba, P., Valladares, M.L, 2010. Upper-Neoproterozoic series in the Central Iberian, Cantabrian and West Asturian-Leonese Zones (Spain): geochemical data and statistical results as evidence for a shared homogenised source area Precambrian Research 178, 51-58.

Valverde-Vaquero, P., Dunning, G.R., 2000. New U-Pb ages for Early Ordovician magmatism in Central Spain. Journal of the Geological Society of London 157, $15-26$

Valverde-Vaquero, P., Díez-Balda, M.A., Díez-Montes, A., Dörr, W., Escuder-Viruete, J., González-Clavijo, E., Maluski, H., Rodríguez-Fernández, L.R., Rubio, F., Villar, P.,
2007. The "hot orogen"; two separate Variscan low-pressure metamorphic events in the Central Iberian Zone. Géologie de la France 2, 168

Vervoort, J.D., Patchett, P.J., Blichert-Toft, J., Albaréde, F., 1999. Relationships between Lu-Hf and Sm-Nd isotopic systems in the global sedimentary system. Earth and Planetary Science Letters 168, 79-99.

Villaseca, C. Barbero, L., 1994. Chemical variability of Al-Ti-Fe-Mg minerals in peraluminous granitoids from Central Spain. European Journal of Mineralogy 6 691-710.

Villaseca, C. Herreros, V., 2000. A sustained felsic magmatic system: the Hercynian granitic batholith of the Spanish Central System. Transactions of the Royal Society of Edinburgh: Earth Sciences $91,207-219$

Villaseca, C., Eugercios, L., Snelling, L.J., Huertas, M.J., Castellón, T., 1995. Nuevos datos geocronológicos (Rb-Sr, K-Ar) de granitoides hercínicos de la Sierra de Guadarrama. Revista de la Sociedad Geológica de España 8, 129-140.

Villaseca, C. Barbero, L., Rogers, G., 1998. Crustal origin of Hercynian peraluminous granitic batholiths of central Spain: petrological, geochemical and isotopic ( $\mathrm{Sr}, \mathrm{Nd}$ ) arguments. Lithos $43,55-79$

Villaseca, C., Downes, H., Pin, C, Barbero, L., 1999. Nature and composition of the lowe continental crust in central Spain and the granulite-granite linkage: inferences from granulitic xenoliths. Journal of Petrology 40, 1465-1496.

Villaseca, C., Bellido, F., Pérez-Soba, C., Billström, K., 2009. Multiple crustal sources for post-tectonic I-type granites in the Hercynian Iberian Belt. Mineralogy and Petrology 96, 197-211.

Villaseca, C., Orejana, D. Belousova, E Armstrong, R.A, Pérez-Soba, C, Jeffries, T.E. 2011a. U-Pb isotopic ages and Hf isotope composition of zircons in Variscan gabbros from central Spain: evidence of variable crustal contamination. Mineralogy and Petrology 101, 151-167.

Villaseca, C., Belousova, E., Ore jana, D., Castiñeiras, P., Pérez-Soba, C., 2011b. Presence of Palaeoproterozoic and Archean components in the granulite-facies rocks of central Iberia: the Hf isotopic evidence. Precambrian Research 187, 143-154.

Woodhead, J.D., Hergt, J.M., 2005. A preliminary appraisal of seven natural zircon reference materials for in situ Hf isotope determinations. Geostandards and Geoanalytical Research 29, 183-195.

Zeck, H.P., Whitehouse, M.J., Ugidos, J.M., 2007a. 496 +3 Ma zircon ion microprobe age for pre-Hercyniangranite, Central Iberian Zone, NE Portugal (earlier claimed $618 \pm$ 9 Ma). Geological Magazine 144, 21-31.

Zeck, H.P., Wingate, M.T.D., Pooley, G., 2007b. Ion microprobe U-Pb zircon geochronology of a late tectonic granitic-gabbroic rock complex within the Hercynian Iberian belt. Geological Magazine 144, 157-177. 